\title{
Corporação, redes técnicas e poder: a trajetória têmporo-espacial da Algar Telecom
}

\author{
Corporation, technical networks and power: the Algar Telecom time-space trajectory
}

\begin{abstract}
Fernando Fernandes de Oliveira Doutor em Geografia e professor do Instituto Federal Goiano Campus Avançado Ipameri, Brasil fernando.oliveira@ifgoiano.edu.br
\end{abstract}

Denis Castilho Doutor em Geografia e professor do Programa de Pós-Graduação em Geografia do IESA/UFG, Brasil

deniscastilho@hotmail.com

\begin{abstract}
Resumo
Os grupos corporativos, nutridos por uma base territorial, se organizam em rede e mantém uma patente sinergia político-econômica com o Estado. As redes técnicas, nesse sentido, insurgem como elementos indispensáveis à configuração multidivisional das modernas corporações, com vistas a equalizar o padrão expansível da acumulação no âmbito de sua natureza multilocalizada. Com base nessas considerações, este texto analisa a trajetória e as práticas espaciais da Algar Telecom (antiga CTBC), uma subsidiária do Grupo Algar, corporação com espesso histórico de atuação no Triângulo Mineiro. Os procedimentos metodológicos basearam-se em análise de anuários estatísticos do IBGE, relatórios da Telebrás, publicações históricas, relatórios do Grupo Algar e mapeamento. O estudo mostra que as redes técnicas se constituem como instrumentos inseparáveis à organização espacial de uma corporação multilocalizada como a Algar Telecom, seja no contexto intra empresa, no externo imediato, no que toca às amarrações políticas ao no conjunto das ações que se fazem sentir à distância.
\end{abstract}

Palavras-chave: Grupo Algar Telecom, Corporação, Redes Técnicas, Poder.

\begin{abstract}
Corporate groups, nourished by a territorial base, are networked and maintain a patent politicaleconomic synergy with the state. Technical networks, in this sense, appear as indispensable elements to the multidivisional configuration of modern corporations, with a view to equalising the expanding pattern of accumulation within its multiloculated nature. Based on these considerations, this paper analyses the trajectory and spatial practices of Algar Telecom (formerly CTBC), the subsidiary of the Algar Group, the corporation with a strong track record in Triangulo Mineiro (a region located in the West of the Brazilian state of Minas Gerais). The methodological procedures were based on analysis of IBGE statistical yearbooks, Telebrás reports, historical publications, Algar Group reports and mapping. The study shows that the technical networks are inseparable instruments for the spatial organisation of a multilateral corporation such as Algar Telecom, either in the intra-company context, in the immediate external, or in the actions that can be felt in the distance.
\end{abstract}

Keywords: Algar Telecom Group, Corporation, Technical Networks, Power. 


\section{INTRODUÇÃO}

Os grupos corporativos tramam redes, agem por meio delas, se configuram enquanto redes. O controle de redes técnicas, nesse sentido, é uma condição sine qua non que retroalimenta a hegemonia desses grupos. Mas a trama não se reduz à dimensão técnica. Ela possui especialmente uma dimensão política pelo modo como as corporações desenvolvem suas ações e estratégias no âmbito territorial. É nessa perspectiva que torna-se possível compreender a proeminência da hegemonia, do privilégio e do poder.

Em perspectiva, os elementos relacionados às ordens técnicas e políticas que embasam os processos de formação socioespacial de um grupo corporativo, ganham importância ante a análise do arranjo espacial inerente ao objeto em destaque, visto que sua geografia expressa um feixe de conexões técnicas, políticas e econômicas. Como sistemas técnicos indispensáveis ao funcionamento das atividades econômicas, a produção e o ordenamento territorial das redes técnicas encontram fundamento no conteúdo político das ações dirigidas pelos grupos sociais. Assim, a evolução técnica e funcional das redes tende a exercer, sob a gerência de corporações privilegiadas, comandos distantes e não raro estranhos ao lugar e aos seus habitantes.

O propósito do presente texto é o de discutir conceitos que confiram inteligibilidade às relações entre redes técnicas, organização em rede e as sinergias político-econômicas mantidas entre corporações e Estado na reorganização do espaço geográfico. Pretende, por meio da discussão teórico-metodológica desenvolvida, analisar a trajetória e as práticas espaciais da Algar Telecom (antiga CTBC), uma subsidiária do Grupo Algar com espesso histórico de atuação no Triângulo Mineiro.

Para tanto, foram analisados Anuários Estatísticos e Planos Nacionais de Desenvolvimento do Instituto Brasileiro de Geografia e Estatística (IBGE), relatórios da Telebrás, Resolução e Decretos relacionados à Regulamentação do Serviço de Comunicação Multimídia e Outorgas de Serviço de Telecomunicações disponíveis em páginas oficiais do Governo Federal. Também foram examinados relatórios do Grupo Algar disponíveis na página virtual da empresa e dados históricos disponíveis em publicações como Jornal do Brasil e Jornal do Commercio.

A narrativa está organizada em quatro momentos. No primeiro analisamos a correlação entre corporação e redes técnicas. A gênese do Grupo Algar Telecom e suas tramas de articulação e sustentação territorial compõem o segundo momento. No terceiro, discutimos as estratégias de diversificação funcional do grupo e, no quarto, a sua organização em rede e atuação em pontos nodais que desembocam na seletividade espacial. 


\section{CORPORAÇÃO E REDES TÉCNICAS}

As práticas de ordenamento territorial executadas pela corporação multiocalizada perseguem a obtenção de ganhos em escala e escopo, na medida em que minimizam as latentes pressões em concorrência, inovação tecnológica e variação mercadológica. Não prescindem, todavia, da constituição de uma trama reticular que favoreça o intercâmbio entre as suas diversas localizações, assim possibilitando o máximo proveito do espaço. Ao atribuírem fluidez e funcionalidade cada vez maiores ao território, as redes técnicas convertem-se em indeléveis instrumentos para a realização de práticas sedimentadas pelo poder e de expansão da modernização pelos lugares.

A corporação multilocalizada, como bem anota Pires do Rio (2000, p. 104), é composta por um arranjo organizacional que porta "ao mesmo tempo, inovação técnico-produtiva, administrativa e financeira que, em se cristalizando como tal, tende a prevalecer como nexo estruturante sobre as demais lógicas, num tempo e espaço determinados”. Essas organizações, na perspectiva institucionalista trabalhada por North (2018, p. 128), são “destinadas por seus criadores a maximizar a riqueza, a renda ou outros objetivos definidos pelas oportunidades proporcionadas pela estrutura institucional da sociedade". No que concerne à dimensão espacial da acumulação capitalista $^{1}$, as grandes corporações, com suas diversas atividades e localizações, constituem grupos fundamentais "da gestão do território, exercendo poderoso controle sobre a organização espacial e sua dinâmica", como nos lembra Corrêa (1991, p. 33).

A disponibilidade de sistemas técnico-reticulares, entrementes, torna-se imprescindível no âmbito das práticas de reprodução de capitais da corporação multilocalizada. Em seu proeminente Strategy and structure, Chandler (1962), anota que os ganhos em eficiência possibilitados pelo conjunto das ferrovias, dos portos fluviais e marítimos e dos sistemas de telégrafos autorizaram notório acréscimo das escalas de atuação das firmas estadunidenses no decorro do século XX. Com efeito, é possível perceber que as redes técnicas insurgem como elementos indispensáveis para a configuração multidivisional das modernas corporações, com vistas a equalizar o padrão expansível da acumulação no âmbito de suas diversas localizações.

Ganha relevo, nessa ótica, o conteúdo organizacional que anima o aparato técnico-reticular disposto no espaço. Segundo Corrêa (2014, p. 109), remete para a configuração interna da entidade estruturada em rede, "abrangendo os agentes sociais, a origem da rede, a natureza dos fluxos, a função e finalidade da rede, sua existência e construção, sua formalização e organicidade”. Daí a emergência de corporações que se organizam de modo reticular, a partir de arranjos técnico-

${ }^{1}$ Para Marx (2013, p. 799), a acumulação de capitais "não é mais do que a reprodução do capital em escala progressiva. Sua dimensão espacial envolve, segundo Harvey (2005, p. 62), "intensificação (dos desejos, das necessidades sociais, de populações totais, e assim por diante) e expansão geográfica" (grifos do autor). 
organizacionais alforriados pela difusão dos suportes materiais que sustentam fluxos e práticas simultâneas, para usar expressões de Castells (2005).

Pensando a trama de empresas "em rede", Mazzali (2000) registra que os arranjos organizacionais geradores de interdependências entre atores variados permitem a coordenação de competências específicas, que visam auferir vantagens diferenciadas no que tange aos processos produtivos, tecnológicos e de inovação. Segundo Silva (2003, p. 30), a corporação em rede é caracterizada por suas múltiplas interações estratégicas, que alinham atores dentro e fora do conglomerado para "inúmeras configurações espaciais, flexibilização de atividades, de recursos e de grupos sociais envolvidos com sua dinâmica”.

A premissa é a da circulação de experiências, saberes organizacionais, inovações e formas adaptativas, na medida em que as redes técnicas destacam-se como instrumentos inseparáveis à organização espacial da corporação multilocalizada, seja no contexto intra empresa, no externo imediato ou no que toca ao conjunto das ações que se fazem sentir à distância. Integra-se, dessa forma, a diversidade espacial referente a grupos, tempos e fluxos de diferentes intensidades ao seu usufruto. A acumulação ampliada dos capitais, outrossim, é o elemento que dá liga aos arranjos técnico-organizacionais, atribuindo um caráter uníssono ao processo que interliga crescente gama de lugares, funções e atores.

Daí a necessidade, para a compreensão da dinâmica dos fluxos que atravessam os fixos espaciais, do entendimento das ações e das estratégias dos grupos que desenham, articulam e comandam as redes, uma vez que elas não se inscrevem sobre o vazio, mas em espaços repletos de história, como bem anota Dias (2005). As redes, por si próprias, não personificam os sujeitos da ação, ainda que sejam plenamente capazes de expressar e definir a escala das ações sociais.

Disso deriva a dimensão política atribuída às redes, percebidas por Raffestin (1993) como imagens do poder exercido por atores dominantes ou deles próprios, de forma que tal poder se faz visível no comando dos complexos aparelhos do território. Santos (2012), por sua vez, advoga que as redes técnicas devem ser entendidas como elemento sociotécnico, uma construção social capaz de expressar a escala de alcance das ações que as anima, visto que sua própria existência mantém sinergia inseparável ao exercício do poder.

Próximo a essa perspectiva, Castilho (2016) aborda a noção de rede a partir de duas variáveis não excludentes. As redes técnicas ou infraestruturais são aquelas que fornecem suporte a toda sorte de fluxos materiais ou imateriais, como as ferrovias, as rodovias e as redes de telecomunicações. As redes de serviço ou de organizações, por seu turno, remetem às ações dos diferentes grupos sociais ante a estrutura técnica para a realização das suas atividades, com notório viés político e social. 
Importa, no processo de espacialização das redes técnicas, a percepção do seu caráter como instrumento da ação deliberada pelos grupos hegemônicos da política e da economia, tal como conferiram autores como Dupuy (1997), Ueda (2002) e Capel (2011). De fato, as corporações multilocalizadas e o Estado acumulam as mais elevadas prerrogativas da gestão do território² ${ }^{2}$ Não há, segundo Santos (2012), uma linha evidente que delimite as suas práticas, na medida em que a produção da fluidez é um empreendimento conjunto dos poderes público e privado.

\section{DA TELEFÔNICA TEIXEIRINHA À CTBC: GÊNESE, CONCHAVOS POLÍTICO- ECONÔMICOS E BASE DE SUSTENTAÇÃO TERRITORIAL}

A Algar Telecom é uma companhia de telecomunicações que acumula mais de 60 anos de atuação no Triângulo Mineiro. É subsidiária e esteio econômico do Grupo Algar ${ }^{3}$, uma corporação multifuncional e multilocalizada com sede em Uberlândia (MG) que atua nos setores de telecomunicações, agronegócio, turismo e hotelaria, táxi aéreo, segurança patrimonial, dentre outras funções.

Extremamente diversificado, o mencionado Grupo registrou, em 2018, Receita Operacional Líquida da ordem de R\$ 2,9 bilhões, empregando aproximadamente 20 mil funcionários (ALGAR, 2019). Estruturada orgânica e espacialmente de modo reticular, a Algar Telecom apresenta um sofisticado portfólio de soluções integradas em Tecnologia da Informação, disponibilizando serviços em telefonia fixa, móvel banda larga fixa e TV por assinatura, além do suporte em contact center, transmissão de dados e TI para clientes corporativos.

A complexidade operacional verificada na atualidade remonta, entrementes, aos eventos pertencentes à própria formação socioespacial do Triângulo Mineiro, sobremodo no que tange às origens das redes ${ }^{4}$ de telefonia na mencionada região. Por sua vez, a gênese dos serviços telefônicos na cidade de Uberlândia ocorreu sob a responsabilidade da Telefônica Teixeirinha, fundada em 1919 pelos irmãos Tito Teixeira e Arlindo Teixeira Júnior. Nesse momento, a companhia possuía uma mesa com capacidade para operar 50 linhas telefônicas.

Num momento em que o privilégio de exploração dos serviços telefônicos era concedido pelas diversas municipalidades, a pulverização das companhias telefônicas ocorreu de forma desenfreada. Ao descrever o período, Ueda (1998, p. 22) anota que "uma gama de decretos, leis,

\footnotetext{
${ }^{2}$ A gestão do território é compreendida por Corrêa (2014) como o conjunto de práticas econômicas e políticas que visam o controle da organização espacial.

${ }^{3}$ Sediado em Uberlândia (MG), o Grupo Algar, cujas origens remontam ao início da década de 1930, compõe uma corporação multifuncional/multilocalizada extremamente diversificada. Atua nos setores de telecomunicações, agronegócio, turismo e hotelaria, táxi aéreo, segurança patrimonial, dentre outras funções.

${ }^{4}$ Para uma análise pormenorizada da implantação e dos efeitos no contexto regional das redes técnicas referentes às ferrovias, estradas de rodagem e eletricidade, ver os trabalhos de Brandão (1989), Bessa (2007), Guimarães (1991; 2010), dentre outros.
} 
cláusulas e regulamentações, o Brasil começou a inserir-se na era da telefonia". Ante essa realidade, a Teixeirinha foi responsável por significativa expansão da telefonia no Triângulo Mineiro. Assim, os serviços telefônicos sediados em Uberlândia logo alcançaram os municípios de Ituiutaba, Monte Alegre, Tupaciguara, Prata e Araguari. Por meio de uma rede incipiente que acompanhava as estradas da Companhia Mineira de Auto Viação Municipal, os telefones da Teixeirinha foram disponibilizados para além dos limites triangulinos, chegando aos municípios de Itumbiara e Buriti Alegre, no estado de Goiás. Com efeito, tratou-se da configuração de um primeiro recorte espacial para os modestos serviços prestados pela empresa telefônica uberlandense, como mostra a Figura 1.

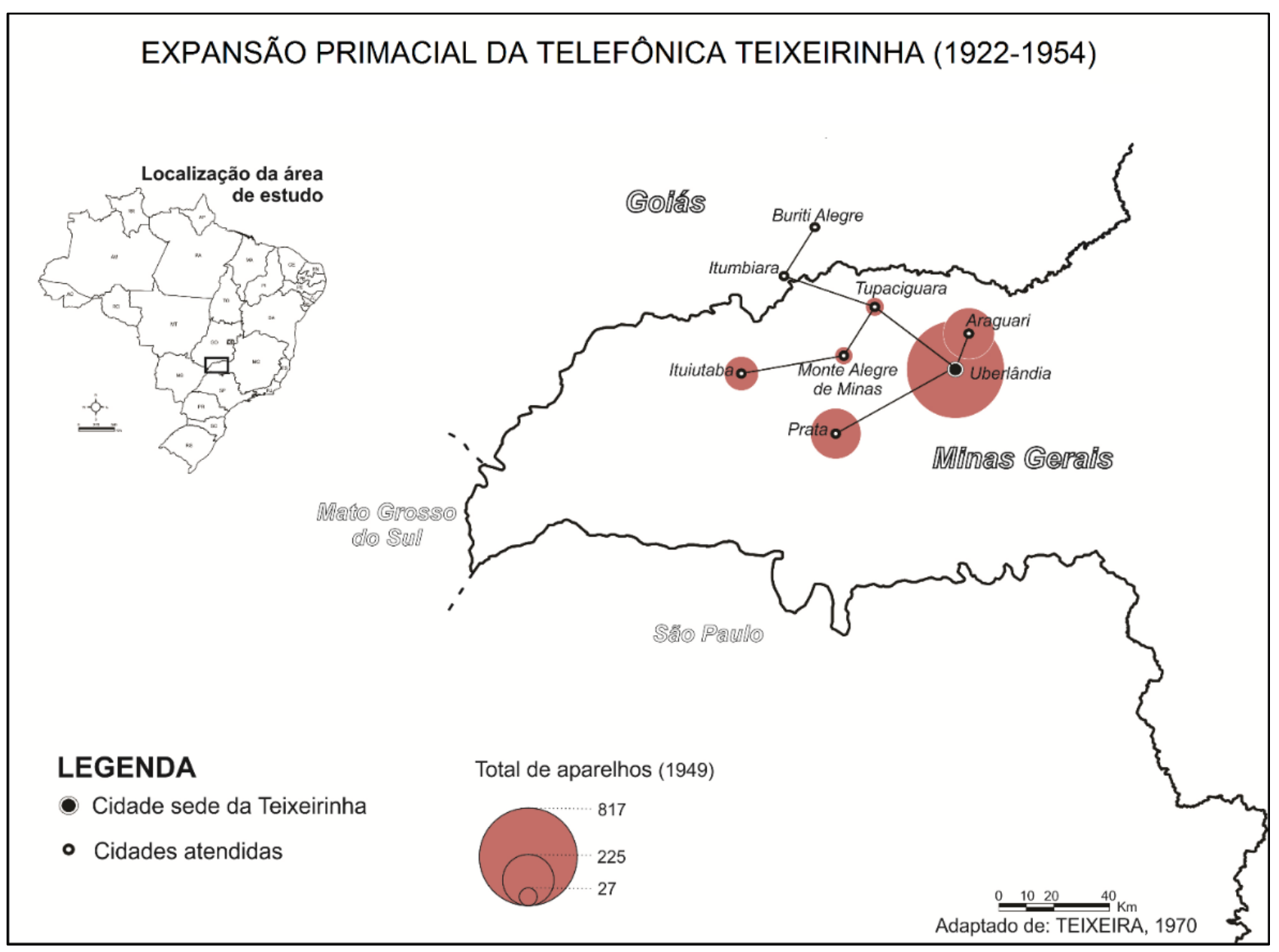

Figura 1 - Telefônica Teixeirinha: primeiro recorte espacial dos serviços telefônicos da Teixeirinha, com densidade de aparelhos em 1949. Fonte: Teixeira, 1970.

Não obstante o acelerado crescimento registrado no início do século, Dias (2008) nos lembra que as décadas de 1940 e 1950 marcaram um tempo de estagnação para as infraestruturas das telecomunicações. Em Uberlândia, a urgência em solucionar as deficiências dos serviços telefônicos contrastava com a incapacidade da Telefônica Teixeirinha em dispor dos capitais necessários para a reestruturação de sua rede de comunicação. 
Coube à Associação Comercial, Industrial e Agropecuária de Uberlândia (Aciapu) ${ }^{5}$, sob a presidência de Alexandrino Garcia ${ }^{6}$ (1953-1955), compor uma comissão para organizar uma firma que sucedesse a Teixeirinha. Nascia, no âmbito das amarrações internas à Aciapu, a Companhia de Telefones do Brasil Central (CTBC) ${ }^{7}$, sociedade anônima responsável por adquirir o acervo patrimonial e as concessões confiadas à Telefônica Teixeirinha. Após um início letárgico e de poucas realizações por parte da CTBC, as mudanças ganharam contornos mais evidentes a partir do ano de 1957, com a instalação de uma central de telefones automáticos.

No entanto, se o desempenho da CTBC mantivera-se modesto no conturbado período subsequente à sua criação, as ações estatais destinadas ao setor das telecomunicações emergiram como grande oportunidade para a reestruturação dos serviços dessa operadora. Firmada em pleno Planalto Central, Brasília exorava estruturar e interiorizar um pujante sistema de conexões telefônicas que proporcionasse agilidade no tráfego das informações com os principais centros do

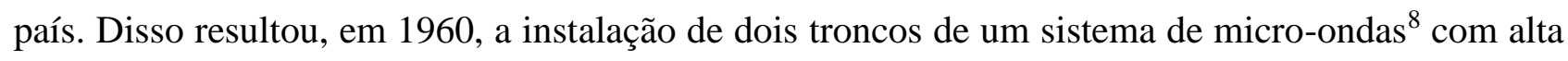
capacidade para executar ligações interurbanas. O primeiro conectara Brasília ao Rio de Janeiro, passando por Belo Horizonte; o segundo, ligara Brasília ao Rio de Janeiro via São Paulo.

As possibilidades provenientes da ação estatal aguçaram as expectativas uberlandenses, sobremodo no que pertencia às lideranças de CTBC e Aciapu. Ainda que o ordenamento de implantação do serviço de micro-ondas em muito suplantasse as requisições sediadas no lugar, o anseio das elites locais baseou-se na tese de que Uberlândia configuraria, de maneira racional, um entroncamento obrigatório do mencionado aparato reticular, de modo que a região atendida pela CTBC pudesse pertencer ao circuito dos pontos atendidos pela proeza técnica.

Em meio às diligências políticas da entidade que representava os capitais locais, tanto Uberlândia quanto Uberaba foram contempladas pelo sistema micro-ondas Rio de Janeiro-Brasília, fixos territoriais que permitiram "o desenvolvimento da telefonia e a diversificação dos serviços de telecomunicações", tal como assinala Dias (2008, p. 123). O investimento do Governo Federal, cujo escopo versava a satisfação das demandas infraestruturais de Brasília, realçou a distinta posição do

\footnotetext{
${ }^{5}$ Atual Associação Industrial e Comercial de Uberlândia - Aciub.

${ }^{6}$ Alexandrino Garcia foi o fundador do atual Grupo Algar, cujo nome fantasia deriva da junção das iniciais de seus nome e sobrenome. Seu primeiro empreendimento foi uma singela máquina de arroz situada na região central de Uberlândia. No momento da fundação da CTBC, Alexandrino desenvolvia atividades como comerciante de combustíveis, automóveis e peças. Não era, como o próprio argumentara, "um homem de telecomunicações" (SILVA, 1993).

${ }^{7}$ Uma assembleia geral foi realizada em 15 de fevereiro de 1954, e, dentre outras pautas, estava a eleição dos diretores e dos conselhos fiscal e consultivo da nova organização. Alexandrino Garcia foi eleito presidente; Elpídio de Freitas, vice-presidente; Hélvio Cardoso e Francisco Caparelli ocuparam as duas vagas que compunham o quadro de diretores da empresa recém organizada.

${ }^{8}$ Os sistemas de micro-ondas, segundo o Anuário de Estatística do Brasil (1980, p. 584), são aqueles que possibilitam "transmissão interurbana, em alta frequência (UHF), através de antenas parabólicas, sem uso de fio, ocupando número determinado de canais e ou circuitos".
} 
Triângulo Mineiro no que concerne ao usufruto do moderno circuito da telefonia, como mostra a Tabela 1.

Tabela 1 - Brasil: rotas dos sistemas de micro-ondas que atendiam Uberlândia e Uberaba em 1970.

\begin{tabular}{cccc}
\hline Programas & Rota & Canais & Distância (em km) \\
\hline \multirow{2}{*}{ Rio-Brasília } & Rio de Janeiro-Juiz de Fora & 1.440 & 165 \\
& Juiz de Fora-Ressaquinha & 1.216 & 90 \\
& Ressaquinha-Belo Horizonte & 1.284 & 137 \\
& Belo Horizonte-Uberaba & 900 & 432 \\
Uberaba-Uberlândia & Uberlândia-Brasília & 888 & 484 \\
São Paulo-Uberaba & São Paulo-Rio Preto & 684 & 307 \\
& São José do Rio Preto-Uberaba & 600 & 170 \\
\hline
\end{tabular}

Fonte: Anuário Estatístico do Brasil (1971). Organizado pelos autores.

$\mathrm{O}$ designo estatal significou, à CTBC, condição fundamental para a reestruturação dos precários serviços e para a difusão espacial das suas concessões originais. A preeminência dessa corporação privada como suporte do desenvolvimento regional triangulino associa-se, como bem anota Guimarães (2010, p. 140), “a esta condição geral que transformou o sistema de telefonia nacional e que, por influência da localização de Brasília, posicionou Uberlândia em condição privilegiada no cenário histórico nacional”. Assim, a reestruturação dos serviços e dos circuitos telefônicos da CTBC passou a ser o foco de Alexandrino Garcia, mediante as possibilidades de expansão de sua área de atuação primacial.

Contudo, a ruptura da legalidade constitucional em 1964, deflagrada no Golpe que conduziu os militares ao poder, concorreu sobremaneira para a valoração estratégica - e estatizante - do que tange do setor das telecomunicações. Esse contexto marcou a criação, em 1965, da Empresa Brasileira de Telecomunicações - Embratel e do Ministério das Comunicações, em 1967. Isso significou, nas palavras de Brandão (1996, p. 77), o rearranjo institucional que colocou, "nas mãos do Estado, o monopólio do setor - uma expressão 'setorial' da integração do mercado nacional".

\footnotetext{
${ }^{9}$ Composto tanto por canas que servem os sentidos das duas localidades quanto destinados a localidades de outras rotas.
} 


\section{DIFUSÃO ESPACIAL, DIVERSIFICAÇÃO FUNCIONAL E O RECRUDESCIMENTO NORMATIVO DAS TELECOMUNICAÇÕES}

Em que pese o avanço do protagonismo estatal e mediante a indiferença das maiores empresas do setor em atender as demandas interioranas, a rede telefônica da CTBC arvoreceu no Triângulo Mineiro, sobremodo no que pertence aos municípios ainda não alcançados pelas técnicas da telefonia. As práticas que caracterizaram o avanço da CTBC sobre os núcleos urbanos triangulinos induziam a configuração de círculos de cooperação capazes de assegurar a realização dos capitais investidos, expondo o predomínio de forças centrípetas baseadas "nas virtualidades materiais e sociopolíticas da área, que permite certa horizontalização da atividade", tal como sugerem Santos e Silveira (2011, p. 291).

Remete-nos, não obstante, ao padrão de difusão por contágio concebido por Hagerstrand (1967), na medida em que a fricção proporcionada pela proximidade faz do entorno o alvo primacial daquilo que se alastra pelo espaço. De modo análogo, Silva (1997) nos ensina que a difusão por contágio na gênese das espacialidades de uma corporação pode resultar da baixa densidade técnica ${ }^{10}$ verificada em determinado contexto têmporo-espacial, o que de fato oportunizou o alargamento das operações da CTBC no Triângulo Mineiro e adjacências. No decurso dos anos 1960, os circuitos telefônicos da companhia em tela alcançaram diversos municípios do Triângulo Mineiro e das porções norte e nordeste do estado de São Paulo, além de concessões em Goiás e Mato Grosso do Sul.

A expressiva difusão dos anos 1970 alcançaria os municípios paulistas de Ituverava, Batatais, Franca, e localidades limítrofes. Nesse contexto, foram incorporadas as empresas telefônicas de Patos de Minas, Carmo do Paranaíba, Luz e Pará de Minas, as duas últimas próximas à capital mineira. O imperativo expansionista da CTBC promoveria, ainda, a incorporação da empresa telefônica da vizinha Uberaba, "rival" histórica de Uberlândia no que concerne à primazia da hierarquia urbana triangulina ${ }^{11}$. Foram adquiridas, ademais, as operadoras dos municípios de Monte Santo e Campos Altos, no sul do estado; além das empresas de Pitanqui, Ibiraci, Lagoa da Prata e Iguatama, na região Central Mineira. Em realidade, os mecanismos de fusão e aquisição consubstanciaram estratégia elementar ao alargamento da rede de lugares atendidos pelos serviços telefônicos da CTBC, como mostra a Figura 2.

\footnotetext{
${ }^{10}$ A densidade técnica é aferida, segundo Santos (2012, p. 257), “pelos diversos graus de artifício" que cada subespaço apresenta.

${ }^{11}$ Como sugere Bessa (2007, p. 173), a importância urbano-regional de Uberaba e Uberlândia no Triângulo Mineiro mantém-se vinculada às práticas e investimentos das suas elites locais, de modo que a posição dos mencionados centros no segmento da rede urbana triangulina não indicam "processos que primavam pela complementaridade e, sim, pela competitividade e pela divisibilidade".
} 


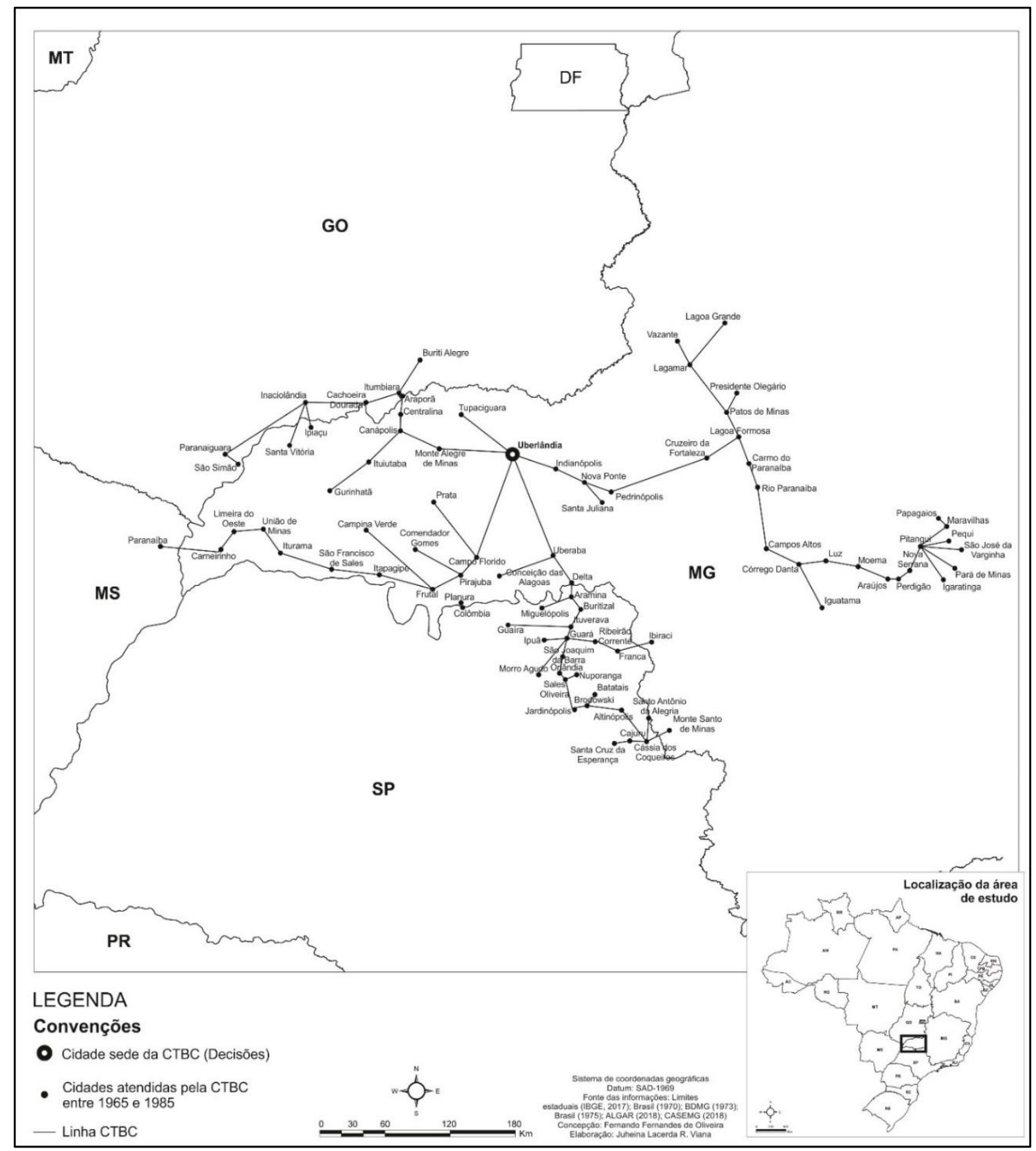

Figura 2 - Área atendida pela CTBC em 1985.

Fonte: Brasil (1970); BDMG (1973); Brasil (1975); Algar (2018).

O alargamento das espacialidades da mencionada corporação não prescindiu da capacidade dos gestores para "modificar, em tempo hábil, regras do jogo econômico, em sua própria área de atividade em função dos seus interesses emergentes", como ensina Santos (2008, p. 59). Daí o sugestivo depoimento de Rondon Pacheco, que ao ocupar cargos no alto escalão do governo estatual, assinou de próprio punho as concessões requeridas por Alexandrino Garcia:

As concessões eram estaduais. Era, de todo modo, um emaranhado jurídico. Em 1961, eu era secretário de estado em Minas, no governo Magalhães Pinto (1961-1966), e o Alexandrino passou a postular para ser o concessionário de todas as concessões caducas do 
Triângulo Mineiro. [...] Tive o privilégio de assinar a concessão, deviam ser umas 40 e tantas concessões, o que já corporificou muito a Telefônica (MUSEU DA PESSOA, 2004).

Todavia, a criação das Telecomunicações Brasileiras S/A - Telebrás, complementaria a reestruturação do setor sob a tutela do Estado autoritário, atribuindo à União a incumbência de "garantir e controlar o permanente funcionamento dos serviços de telecomunicações" (BRASIL, 1972). No formato de holding, o Sistema Telebrás (STB) congregou, além de 27 empresas-polo estabelecidas nos estados, quatro operadoras autônomas ${ }^{12}$, porém funcionalmente integradas ao arranjo das telecomunicações na égide do monopólio estatal. A CTBC, mediante um conflituoso jogo de amarrações políticas atadas junto ao poder concentrador dos governos militares, foi a única operadora vinculada ao STB a continuar sob o comando da iniciativa privada.

No que concerne às deliberações políticas que permitiram à CTBC permanecer sob o domínio da família Garcia, a figura de Rondon Pacheco foi, mais uma vez, fundamental ao acolhimento das solicitações encaminhadas. Este político uberlandense exerceu sucessivos mandatos como deputado federal (1950-1967), atuando ainda como chefe do Gabinete da Casa Civil durante o governo de Costa e Silva (1964-1969), e como governador de Minas Gerais (19711975), por meio de indicação direta do Executivo Federal. Reconhecido por sua hábil interlocução, Rondon Pacheco possuía trânsito acessível aos bastidores dos governos militares, donde foram tecidas as articulações políticas entre o ímpeto estatizante e a resistência privatista de Alexandrino e Luiz Alberto Garcia. Em depoimento, o mencionado político descreve o conflituoso jogo de interesses superpostos no que concerne à manutenção da CTBC como uma empresa privada:

Quantas vezes tive de interferir [...]. A Embratel estava nas mãos do general Galvão, o
Alencastro. Eram todos militares, e tinha-se de conviver com isso, mas houve muita
compreensão. Eu era acionado pelo Dr. Luiz e pelo Sr. Alexandrino, quando necessário.
Eles também sabiam das minhas ocupações, mas nunca tiveram cerimônia para me
procurar, porque sabiam da minha identidade com os interesses superiores da nossa região,
do estado, do interesse público. Nesses momentos mais críticos, eu procurava os poderes de
decisão, os centros de decisão. E eu estava sempre muito afeito a eles porque tive nas mãos,
por destinação funcional, lá na Casa Civil - eu não estava assim como peixe fora d'água -
de comprar várias brigas, por delegação do presidente da República, porque ele queria,
precisava ser feito: "Eu quero inaugurar a Embratel, eu quero que o papa esteja falando para
todo o Brasil e aqui seja visto" (MUSEU DA PESSOA, 2004).

No que tange às pressões exercidas pelo monopólio estatal e às diligências políticas que garantiram sobrevida à empresa telefônica dos Garcia, a CTBC perdeu, na segunda metade da década de 1970, algumas de suas concessões anteriores, a exemplo dos municípios de Morrinhos e Goiatuba, em Goiás; Bambuí, em Minas Gerais; e Barretos, no estado de São Paulo. Os

\footnotetext{
${ }^{12}$ Refere-se à Serviços de Telecomunicações de Londrina - Sercomtel, da Prefeitura Municipal de Londrina (PR); à Centrais Telefônicas de Ribeirão Preto - Ceterp, da Prefeitura Municipal de Ribeirão Preto (SP); e à Companhia Riograndense de Telecomunicações - CRT, do estado do Rio Grande do Sul.
} 
estranhamentos conheceram o auge quando a central telefônica de Itumbiara (GO) foi invadida por militares, situação que demandou, mais uma vez, o intento apaziguador de Rondon Pacheco, que assim relatou os acontecimentos:

Eu era obrigado a usar diplomacia. Algodão entre cristais. [...] Eu lembro que houve um episódio, eu não sei precisar exatamente os lances, em que os policiais militares, o exército, ocuparam a central. Lembro do momento em que o Luiz ligou para mim, e eu disse a ele: "Luiz, me liga daqui a pouco que eu vou ver". E ele dizia para mim: "Não vou ligar, vou ficar na linha esperando o senhor voltar". Ele estava aflito, angustiado. E isso eu tinha de defender (MUSEU DA PESSOA, 2004).

Em que pese os conflitos e as amarrações políticas que determinaram o futuro da CTBC como uma corporação de capital privado, cumpre registrar os limites impostos ao processo de difusão espacial na aurora da década de 1980, em função das restrições fixadas pelo advento do Sistema Telebrás. Ante as dificuldades relativas à aferição de dados que demonstrem a evolução da densidade telefônica na área atendida pela CTBC, a marca de 100.000 aparelhos foi conquistada em 1982. A título de comparação, o Sistema Telebrás alcançara 6.647 localidades neste ano, disponibilizando um total de 9.058.000 aparelhos (TELEBRÁS, 1982). Desta forma, os pontos de acesso gerenciados pela CTBC correspondiam a 1,1\% das linhas instaladas pelo STB no ano mencionado, dando-nos uma ideia da proporção diminuta da companhia uberlandense quando comparada à amplitude do monopólio estatal.

Perante a possibilidade de estatização da CTBC, as estratégias espaciais e organizacionais dos atores em pauta visaram promover uma maior diversificação funcional. Disso resulta a emergência do Grupo $\mathrm{ABC}^{13}$, em 1982, para aglutinar o leque de atividades desenvolvidas pela família Garcia, dentre as quais a proeminente companhia telefônica. Não obstante, a diversificação prenunciada não prescindiu do aproveitamento das oportunidades referentes ao largo contexto da reestruturação dos padrões de acumulação sob a legitimidade do planejamento territorial via intervenção do Estado autoritário.

Como exposto na proposta do II Plano Nacional de Desenvolvimento (1975-1979), os incentivos governamentais buscaram executar "projetos de vanguarda, com esforço próprio de inovação tecnológica” (BRASIL, 1974, p. 18), com destaque aos setores termonuclear, bélico, aeroespacial, da eletroeletrônica ${ }^{14}$, da teleinformática e da computação. No lastro da política

\footnotetext{
${ }^{13}$ Reestruturado na primeira metade nos anos 1990, foi renomeado como Grupo ABC Algar e, finalmente, Grupo Algar. Como ensina Pires do Rio (2000, p. 103), as alterações na arquitetura organizacional de uma corporação "estão intimamente relacionadas às estratégias de crescimento como ampliação do mercado, aumento da escala de atuação, investimentos em novos negócios, adoção de novas tecnologias e padrões de administração".

${ }^{14}$ O Decreto $n^{\circ} 70.370$ de 5 de abril de 1972 criou a Comissão de Coordenação das Atividades de Processamento Eletrônico (CAPRE). Dentre outras atribuições, coube à CAPRE propor "medidas pendentes à formulação de uma
} 
nacionalista, os capitais privados domésticos foram encorajados a investirem no desenvolvimento tecnologia de ponta, por meio da "articulação entre Estado, corporações privadas e o sistema científico-tecnológico", tal como assinalam Becker e Egler (1994, p. 130).

Munidos do conhecimento técnico e operacional, dos capitais acumulados no âmbito dos serviços explorados pela CTBC e das oportunidades geradas a partir das reservas de mercado instituídas pela intervenção estatal, os empreendedores uberlandenses diversificaram as suas atividades rumo aos setores de vanguarda tecnológica. Foram adquiridas, dessa forma, subsidiaras ${ }^{15}$ que atuavam na industrialização de equipamentos em informática e teleinformática, eletroeletrônicos e fibras ópticas, ramo no qual o Grupo ABC possuía exclusividade. Ante tal realidade, cumpre registrar que o pioneirismo desse grupo na região triangulina, tendo esta área como base de sustentação territorial, somado às políticas setoriais que buscaram o domínio do "vetor científico-tecnológico moderno" sob intervenção estatal, representaram condições precípuas para a diversificação funcional dos capitais organizados pela família Garcia. Um indicativo, ante as pressões pela estatização da CTBC, da contraditória relação estabelecida entre os mencionados empreendedores e as ações do Estado interventor.

\section{A PERFORMANCE DO GRUPO ALGAR NO CONTEXTO DA PRIVATIZAÇÃO DO SISTEMA TELEBRÁS}

Única operadora de telefonia sob o domínio privado após a instituição do Sistema Telebrás, em 1972, a CTBC havia incorporado uma área de cobertura de 102.000 km², assim articulada por meio de estrutura própria de fixos telefônicos ${ }^{16}$. De sorte que as 270 localidades assistidas por seus serviços conectavam-se a Uberlândia (MG), cidade que se constituiu como importante centro de gestão de uma verdadeira organização territorial em rede.

Em 1991, a CTBC operava 270.000 terminais telefônicos numa área que abrigava aproximadamente 2.300.000 habitantes. Sua amplitude territorial apresentava uma densidade telefônica de 11 pontos de acesso por grupo de 100 habitantes, de maneira que as operações contavam com 5,5 funcionários para cada 1.000 aparelhos em serviço ${ }^{17}$. A título de comparação, o Sistema Telebrás possuía, em 1990, um total de 5,8 telefones instalados para cada 100 indivíduos, ao passo que o número de funcionários por 1.000 aparelhos chegava aos 10 (TELEBRÁS, 1990).

\footnotetext{
política de financiamento governamental ao setor privado, para a atividade de processamento de dados" de maneira a instituir reservas aos empreendedores nacionais.

${ }^{15}$ Em teleinformática, destacam-se as subsidiárias Telettra e Intaltel; em informática, a ABC Bull, em parceria com o grupo francês Honeywell Bull; em produção de fibra óptica, a ABC X-Tal. No âmbito do Grupo Algar, essas funções foram sendo paulatinamente excluídas no decurso da década de 1990.

${ }^{16}$ Conforme já pontuado, o período mais expressivo da difusão espacial da CTBC se deu entre o final da década de 1960 à primeira metade dos anos 1980, momento em que a regulação estatal recrudescera a continuidade da expansão.

${ }^{17}$ Jornal do Brasil (17/10/1991, p. 3 - negócios e finanças).
} 
No que concerne aos custos de instalação por linha, a companhia telefônica do Grupo Algar mantinha-se mais eficiente quando comparada à média dos indicadores da holding estatal: US\$ 1.500 contra US\$ 3.000 unitários.

É necessário registrar o pioneirismo da CTBC para a disponibilização do serviço de telefonia móvel em porções interiores do território nacional, a partir de 1992. Antes mesmo que os celulares estivessem disponíveis em metrópoles como São Paulo e Belo Horizonte, a primeira etapa do projeto executado pela CTBC destinou 2.800 terminais para os três principais centros urbanos de sua área de concessão: Uberaba e Franca receberam 800 linhas cada, enquanto Uberlândia foi comtemplada com 1.200 acessos. Já em 1995, passou a prestar serviços em TV por assinatura (ALGAR, 2012), cobrindo 25.000 pontos nas triangulinas Uberlândia e Araguari.

Contudo, a década de 1990 prenunciara um conjunto de mudanças estruturais encaminhadas por solicitações exógenas, porém afiançadas por novos arranjos institucionais internos. Segundo Castells (2005, p. 178), as transformações perseguiram a "desregulamentação das atividades econômicas domésticas [...]; a liberalização do comércio e dos investimentos internacionais; e a privatização das empresas públicas", de forma que o sistema brasileiro de telecomunicações emergiu como um vetor de primeira ordem aos anseios alienígenas mediante a expectativa de ruptura da exclusividade estatal.

Em realidade, a desestatização do setor prenunciava um contexto desafiador à CTBC, ante o ingresso dos capitais multinacionais no mercado brasileiro de telecomunicações. A privatização do STB ocorreu em 1998, por meio da cisão da holding estatal em doze sociedades anônimas ${ }^{18}$ e do estabelecimento de quatro grandes regiões geográficas estipuladas pelo Plano Geral de Outorgas ${ }^{19}$ da telefonia fixa, como mostra a tabela 2.

Tabela 2 - Regiões do Plano Geral de Outorgas (PGO), 1998.

\begin{tabular}{cc}
\hline REGIÃO & ÁREA GEOGRÁFICA CORRESPONDENTE AOS TERRITÓRIOS \\
\hline I & $\begin{array}{c}\text { os estados de Rio de Janeiro, Minas Gerais, Espírito Santo, Bahia, Sergipe, } \\
\text { Alagoas, Pernambuco, Paraíba, Rio Grande do Norte, Ceará, Piauí, } \\
\text { Maranhão, Pará, Amapá, Amazonas e Roraima. }\end{array}$ \\
II & o Distrito Federal e os estados do Rio Grande do Sul, Santa Catarina, \\
Paraná, Mato Grosso do Sul, Mato Grosso, Goiás, Tocantins, Rondônia e & Acre. \\
III & o estado de São Paulo. \\
IV & todo o território nacional. \\
\hline
\end{tabular}

Fonte: Brasil (1998). Organizado pelos autores.

\footnotetext{
${ }^{18}$ Em telefonia fixa, Tele Norte Leste, Tele Centro Sul, Telesp e Embratel (ligações de longa distância); em telefonia celular, Telesp Celular, Telemig Celular, Tele Celular Sul, Tele Centro-Oeste Celular, Tele Norte Celular, Tele Nordeste Celular, Tele Sudeste Celular e Tele Leste Celular. Conforme mencionado, a Lei no 9.295/1996 já havia autorizado a Telebrás a constituir subsidiárias para a exploração do serviço de telefonia móvel.

${ }^{19}$ Ajuizado pelo Decreto ${ }^{\circ} 2.537$ de 2 de abril de 1998 .
} 
A peculiaridade que conferiu à CTBC o status de única operadora privada no âmbito do antigo STB não passaria ao largo na consolidação de uma nova geografia das telecomunicações no Brasil. Como esclareceu o então presidente da Anatel Renato Narravo Guerreiro ao periódico $O$ Estado de São Paulo ${ }^{20}$, o processo de privatização do Sistema Telebrás preservaria, como direito adquirido, as concessões pregressas da corporação uberlandense. Os setores 3, 25 e 33, respectivos das regiões I, II e III, foram exclusivamente compostos pela rede de municípios da subsidiária do Grupo Algar conforme as suas localizações pregressas ${ }^{21}$, de maneira que o município de Paranaíba (MS) compôs sozinho o setor 22 da região II. Em que pese o seu reduzido espaço de atuação perante a escala do território nacional, a CTBC acabou por possuir concessões nas três grandes regiões de outorgas do novo recorte geográfico do serviço brasileiro de telefonia fixa, como retrata a Figura 3.

O decurso das inovações setoriais anunciou importante diversificação em torno das soluções convergentes em tecnologia da informação e comunicação (TIC). Dizem respeito, sobremodo, à inauguração da Algar Call Center Service (ACS) e do incremento das operações Comunicação Multimídia (dados, voz e imagem), ambos firmados a partir de 1998. Locada num prédio edificado exclusivamente ${ }^{22}$ para o desenvolvimento de atividades relativas ao telemarketing, a ACS contava com 800 posições iniciais de contact center, atendendo clientes do calibre de American Express, TAM, Intelig, Monsanto, Armazém Martins, além das próprias necessidades.

Desta forma, a crescente demanda por tais serviços faria a capacidade de operação alcançar as 2.500 posições já no ano de 2000 e, em 2005, inaugurou uma unidade de contact center com 1.500 posições em Campinas (SP). Por seu turno, as operações ${ }^{23}$ em Comunicação Multimídia (dados, voz e imagem) via internet banda larga ganharam contornos mais evidentes a partir da estruturação de uma rede própria de fibras ópticas na diminuta área de abrangência da CTBC. Após o cumprimento das metas de universalização do serviço de telefonia fixa, a CTBC recebeu

\footnotetext{
${ }^{20} 11 / 07 / 1998$ - economia, p. B-7.

${ }^{21} \mathrm{Em} 1998$, os municípios pertencentes à área de cobertura da CTBC foram os primeiros do país a receberem serviços de telefonia celular por meio do sistema pré-pago. Conforme notificou o periódico Jornal do Commercio (06/03/1998, p. A-20 - empresas), a novidade foi desenvolvida em parceria com a joint-venture Global One (derivada da associação entre a estadunidense Sprint, a alemã Deutsche Telecom e a francesa France Telecom). Tornando-se tendência em telefonia móvel nos anos posteriores, os cartões pré-pagos foram disponibilizados nos valores de $\mathrm{R} \$ 25, \mathrm{R} \$ 40$ e $\mathrm{R} \$ 70$ e possibilitavam maior controle de gastos com os aparelhos celulares.

${ }^{22} \mathrm{O}$ edifício que abrigou a ACS em Uberlândia foi o primeiro do país estruturado exclusivamente para fins de receber instalações de telemarketing. Inclui, dentre outros, serviços de atendimento a clientes, vendas, crédito e cobrança. Em 2017, contava com 7.500 posições de atendimento nos sites de Campinas e Uberlândia (ALGAR, 2017).

${ }^{23}$ Cumpre registrar que essa atividade não prescindiu da geração de sinergias junto a corporações multinacionais, tais como as estadunidenses Unisys e Oracle, especializadas em sistemas integrados de processamento da informação.
} 
autorização da Anatel para expandir suas redes de telefones fixos e do Serviço de Comunicação Multimídia $(\mathrm{SCM})^{24}$, a partir de 2002.

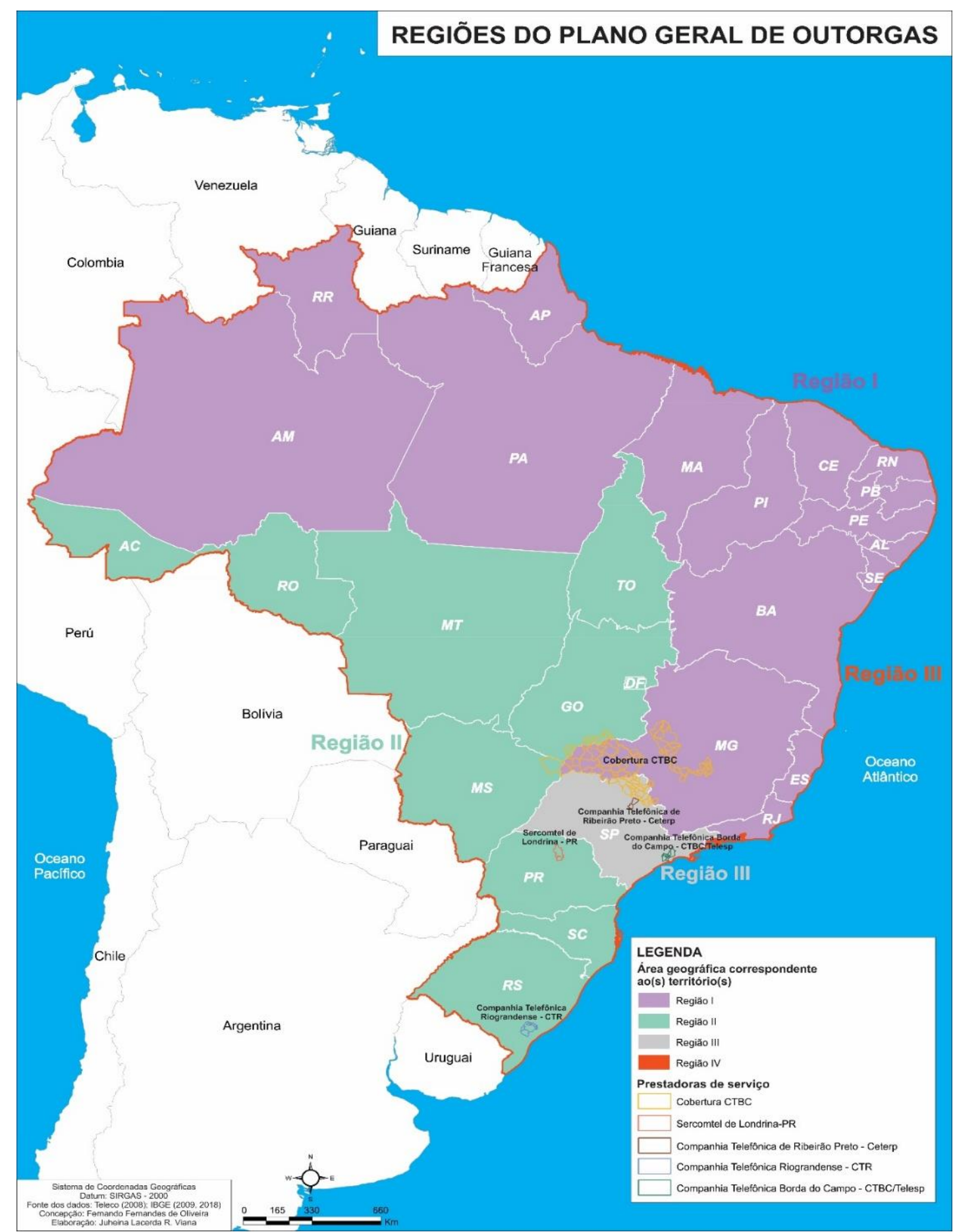

Figura 3 - Divisão da telefonia fixa no âmbito do Plano Geral de Outorgas, 1998.

Fonte: Teleco (2008), IBGE (2009, 2018).

\footnotetext{
${ }^{24}$ Segundo a Resolução n ${ }^{\text {o }}$ 614, de 28 de maio de 2013, o SCM "é um serviço fixo de telecomunicações de interesse coletivo, prestado em âmbito nacional e internacional, no regime privado, que possibilita a oferta de capacidade de transmissão, emissão e recepção de informações multimídia, permitindo inclusive o provimento de conexão à internet, utilizando quaisquer meios, a Assinantes dentro de uma Área de Prestação de Serviço" (BRASIL, 2013), outorgada pela Anatel.
} 
Munindo-se de estratégias de fusão, aquisição e seletividade espacial, a corporação uberlandense comprou, em 2004, o provedor de internet denominado NetSite, estabelecido em Ribeirão Preto (SP). Em 2005, adquiriu o ativo da empresa Iqara Telecom, portadora de uma óptica com $172 \mathrm{~km}$ de extensão que abraçava a região metropolitana de São Paulo para subsidiar demandas corporativas em conectividade e transmissão de dados. Doravante, as estratégias de ordenamento espacial da então renomeada Algar Telecom podem ser caracterizadas por meio dos aspectos funcionais e das práticas espaciais que amarram a área de concentração horizontal preestabelecida aos ditames das frentes de concentração vertical ${ }^{25}$.

No recorte das concessões originais, cuja outorga foi renovada por mais 20 anos em 2005, a estratégia perseguiu aperfeiçoar e disponibilizar pacotes que integram telefonia e internet (fixa e móvel) $)^{26}$, TV por assinatura, listas e guias telefônicos. O escopo visa resguardar as áreas de concentração horizontal, constituída por um mercado no qual a corporação mantém densa capilaridade e largo período de atuação. A Algar Telecom possui, em sua área de cobertura primacial, 1.290.000 clientes em telefonia móvel, 736.000 em telefonia fixa, 543.000 em banda larga fixa, e 83.000 em TV por assinatura (ALGAR TELECOM, 2018), num total de 2.652.000 unidades geradoras de receitas em varejo.

As práticas espaciais das frentes de concentração vertical ${ }^{27}$ perpassam pelo ordenamento da óptica que a Algar Telecom vem edificando a partir do seu recorte horizontal. Com efeito, a difusão dessa estrutura obedece a estratégia de seletividade espacial que privilegia os centros urbanos bem posicionados em suas respectivas redes urbanas, portadoras de vastas hinterlândias, mercados diversificados, e sedes de empresas sequiosas pela fluidez operacional que os serviços em data center/multimídia e contact center podem oferecer. Operando sobre plataforma VoIP ${ }^{28}$, o sofisticado backbone óptico possui aproximadamente $61 \mathrm{mil} \mathrm{km}$, divididos em 50 mil km terrestres e outros 11 mil km de cabos submarinos que conectam os estados de São Paulo e Ceará à Flórida, nos Estados Unidos. Com base nos dados disponibilizados por Anatel (2019), a Figura 4 expõe a

\footnotetext{
${ }^{25}$ Corrêa (2014) classifica, no âmbito das espacialidades de uma corporação, a área de concentração horizontal como o momento no qual a empresa bem sucedida adquire empresas do mesmo segmento ou cria novas unidades para além de seu ponto primacial. A concentração vertical, por seu turno, diz respeito a unidades funcionalmente integradas entre si, que realizam operações tecnicamente situadas tanto a jusante como a jusante da operação básica. O operar esses dois modos de expansão, a corporação tornar-se-á tanto multilocalizada como multifuncional.

${ }^{26}$ É necessário registrar que no decurso da década de 2000, a Algar Telecom promoveu, em telefonia celular, a transição da tecnologia TDMA para o modelo Global System for Mobile Communications - GSM em 2004. Esse sistema utiliza um cartão SIM (Subscriber Identity Module, o popular "chip" de celular). Desse, evoluiu-se para a tecnologia de terceira geração (3G), incorporada pela mencionada companhia em 2008 (ALGAR, 2009).

${ }^{27}$ Envolvem, nesse contexto, as estratégias de fusão e aquisição de outras corporações, com destaque às empresas Synos Technologies, em 2010; Asyst, em 2014; Optitel Redes e Telecomunicações, em 2015; de uma estrutura óptica da Cemig, em 2018; e do provedor de internet Smart Telecomunicações e Serviços LTDA, em 2019 (ALGAR, 2017 ; ALGAR TELECOM, 2019).

${ }^{28}$ Oriundo do termo em inglês voice over internet protocol - VoIP, o termo faz referência ao uso da internet para a comunicação de voz.
} 
dimensão espacial dos 583 municípios que integram a rede, assim como a densidade das 56.303 portas de acesso por cada ponto do espaço.

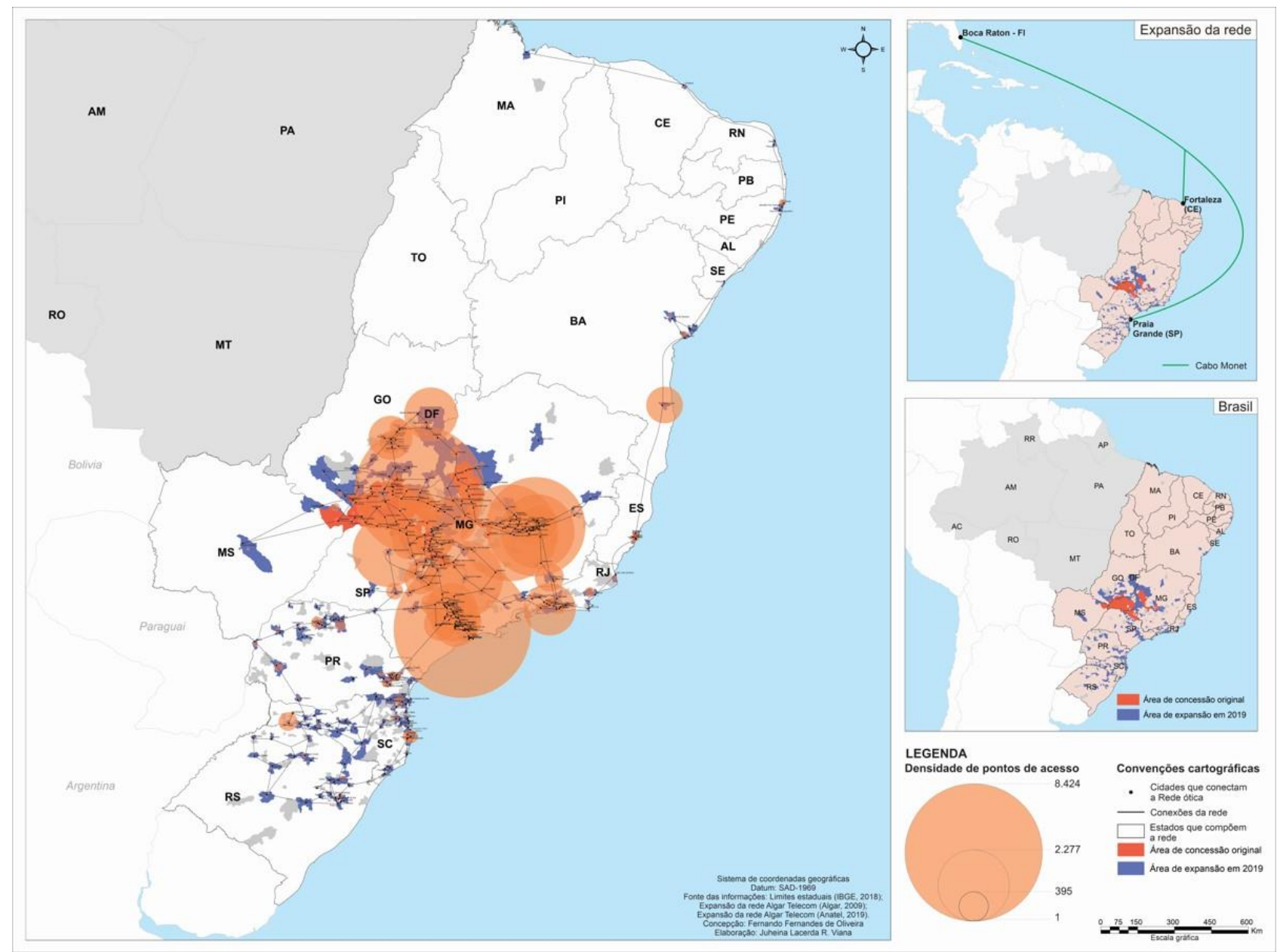

Figura 4. Algar Telecom: dimensão da rede óptica e densidade dos pontos de acesso, 2019.

Fonte: IBGE (2018), Algar (2009), Anatel (2019).

Como insumo valioso ao trânsito instantâneo de ordens e informações, a irradiação desse aparato técnico se faz sobre áreas onde o conteúdo informacional das atividades econômicas possui maior influência. A região Sudeste comporta 305 municípios, o que corresponde a 52,3\% do total. Os 222 municípios da região Sul representam 38\% dos pontos articulados. No Centro-Oeste, foram contabilizados 39 municípios (6,6\%); o Nordeste, como fronteira mais recente à difusão espacial dessa rede, possui 15 (2,5\%) unidades municipais integradas. Na região Norte, apenas as cidades de Manaus e Belém fazem parte da tessitura óptica do Grupo Algar, correspondendo a ínfimos 0,34\% do total.

No mercado corporativo business to business (B2B), são 104.791 clientes atendidos (AGAR TELECOM, 2018), assim aderidos à rede de soluções convergentes em Business Process 
Ousurcing (BPO) ${ }^{29}$, gestão em Tecnologia da Informação, contact center (atendimento ao cliente, telemarketing, vendas e cobranças), data center e multimídia (nuvem e tráfego de dados, voz e imagens via backbone próprio). Destarte, essa trama reticular se faz presente em importantes centros nodais das regiões Sudeste, Sul, Centro-Oeste e Nordeste. Alcança, ademais, Argentina, Colômbia, México e Estados Unidos, de forma que a presente organização espacial da Algar Telecom releva a trama reticular de uma corporação multinacional.

A descontinuidade geográfica não se impõe como fator limitante ao intercâmbio, uma vez que a versatilidade dessas redes informacionais, elemento que justifica a adesão dos atores a essa tessitura de complementaridades, é condição precípua ao trânsito simultâneo das informações. Ao estabelecer alianças estratégicas com outros grupos, a atual diversificação da Algar Telecom faz emergir redes organizacionais ${ }^{30}$ amparadas no estrato técnico-reticular difuso no espaço geográfico. Embora não prescinda das potencialidades aferidas nos subespaços para a realização das interdependências, a preeminência dessas redes ganha efetividade na medida em que as interações entre os diversos grupos envolvidos avolumam e ampliam suas tramas. Segundo Capra (2008, p. 25),

Quanto mais pessoas estiverem engajadas nessas redes, mais desenvolvidas e sofisticadas as redes serão, e mais bem preparada estará a organização para aprender e responder criativamente a novas circunstâncias, transformar-se e desenvolver-se. Em outras palavras, a vivacidade das organizações está nas comunidades de práticas.

Para materializar essa constelação de pontos verticalizados, a corporação muniu-se de práticas que visaram reforçar os seus alicerces financeiros, tais como o processo de emissão de debêntures ${ }^{31}$ e de empréstimos acertados junto aos órgãos de fomento, com destaque ao BNDES ${ }^{32}$. Uma vez mais, a deliberação estatal apresenta-se como elemento precípuo das estratégias de crescimento e difusão espacial de uma grande corporação, assim acrescida em poderes econômicos e políticos.

\footnotetext{
${ }^{29}$ Refere-se, grosso modo, à terceirização de processos que utilizam com intensidade a tecnologia da informação. No que concerne à Algar Telecom, os serviços em BPO estão relacionados a Gestão de Relacionamento com Clientes, Gestão do Ambiente de Tecnologia e Gestão de Serviços de Telecom (ALGAR TELECOM, 2019).

${ }^{30}$ Corrêa (2014, p. 109), sugere que na dimensão organizacional das redes geográficas estão presentes elementos relativos à sua configuração interna, tais como "os agentes sociais, a origem da rede, a natureza dos fluxos, a função e finalidade da rede, sua existência e construção, sua formalização e organicidade".

${ }^{31}$ Segundo a Lei ${ }^{\circ}$ 10.303/2001, a debênture é um valor mobiliário emitido via oferta pública por sociedades anônimas. Refere-se a uma fração de empréstimo acertado entre a companhia emissora e os compradores, com prévio registro na Comissão de Valores Imobiliários (CVM), órgão que disciplina as emissões. Representa, desta forma, um mecanismo de captação de recursos adicionais.

${ }^{32}$ Uma breve consulta ao site do BNDES aponta que, entre os anos de 2005 e 2012, as subsidiárias do segmento em telecomunicações do Grupo Algar aponta a ocorrência de 11 contratos firmados entre as mencionadas instituições. Em sua maioria, os projetos estiveram ligados à expansão da rede óptica estruturada pela corporação uberlandense.
} 
Alinhada aos ditames da divisão territorial do trabalho, a organização reticular da Algar Telecom perpassa por estratégias de seletividade espacial privilegiando pontos nodais aptos a participarem dessa trama de complementaridades. Sob o comando de sua rede técnicoorganizacional, são reveladas as nuanças de uma hierarquia urbana baseada na densidade econômica e no potencial produtivo de cada ponto do espaço, de forma que um conjunto de realidades espaciais díspares é articulado pelo ímpeto das redes técnicas e pelo ordenamento distante.

\section{CONSIDERAÇÕES FINAIS}

A trama espacial de uma corporação que se organiza em redes, que articula e se sustenta em redes técnicas, tal como a Algar Telecom, possui base no movimento sincrônico que a leva a configurar uma série de segmentações técnicas, sociais e territoriais do trabalho hierarquicamente tipificadas. Disso resulta uma sequência de eventos imprescindíveis à própria análise, na medida em que o movimento de consolidação horizontal e de expansão vertical da corporação em rede faz insurgir subsistemas passíveis de delimitação, cujas múltiplas interações relacionais dão conta de uma composição espaço-temporal de técnicas, normas, grupos e ações.

Dos módicos serviços prestados pela Telefônica Teixeirinha, perpassando pelas possibilidades emergentes com a nova capital federal inaugurada ao recrudescimento do Sistema Telebrás, a dinâmica espaço-temporal do objeto em destaque atesta a ocorrência de sucessivos redimensionamentos de ordem técnica, organizacional e política. A amarração de tessituras políticas junto aos representantes do poder estatal (seja na escala local/regional, seja na escala nacional) perseguiram, ao mesmo tempo, conter o ímpeto estatizante, manter sua base de sustentação territorial e acessar as oportunidades de diversificação no lastro da política nacionaldesenvolvimentista, seja como ação oportunista para acessar o favorecimento, seja como ação estratégia para evitar a absorção pelo Estado. Ademais, a pregressa acumulação de capitais e de conhecimento organizacional, o espesso histórico de atuação e a densa capilaridade de sua rede nas áreas de concentração horizontal, possibilitaram à atual Algar Telecom uma série de vantagens comparativas quando da privatização do Sistema Telebrás.

O peso dessas prerrogativas embasou não só a permanência dessa corporação como empresa privada no acirrado mercado das telecomunicações brasileiras do período posterior à ruptura do monopólio estatal, mas a deflagração das estratégias de expansão vertical verificadas no presente. Manifesta-se, nesse contexto, uma fase marcada pela preeminência de articulações atadas com diversos grupos econômicos, de forma que as interações intra e extra empresa buscam integrar “competências complementares”, para usar a expressão de Mazzali (2000). Alteram-se, também, as 
relações com o próprio Estado, visto o seu destacado papel de provedor, via BNDES, de financiamentos subsidiados com recursos públicos e condições facilitadas, amiúde destinados a auxiliar as estratégias de expansão de grandes grupos corporativos.

Em realidade, a trajetória têmporo-espacial da Algar Telecom denota a emergência de uma privilegiada corporação em rede, assim acrescida de notória capacidade para fazer prevalecer as suas demandas político-econômicas junto às esferas do poder público. Com efeito, a propriedade de suas práticas de ordenamento e sustentação territorial deriva dessa capacidade de adaptação ante a mudanças de ordem técnica e macroeconômica, elemento fundamental para a compreensão da complexa trama de múltiplas funções e localizações apresentada.

\section{REFERÊNCIAS}

ALGAR. Relatório de Sustentabilidade de 2012. Disponível em: <https://www.globalri.com. br/algar/2012/inc/pdf/Algar-Telecom-RA-2012.pdf>. Acesso em: 01 fev. 2019.

. Disponível em <https://www.algar.com.br/>. Acesso em: 25 jun. 2019.

ALGAR TELECOM. Relatório de Sustentabilidade 2018. Disponível em < https://algar2019.nambbu.com.br/a-algar-telecom/nossa-trajetoria/>. Acesso em: 09 jun. 2019.

<https://ri.algartelecom.com.br/wp-content/uploads/sites/13/2019/03/Algar-Telecom_ Fato-Relevante_Proj-Surfside_final.pdf>. Acesso em: $11 \mathrm{dez} .2019$.

ANATEL. Dados. 2019. Disponível em: <https://www.anatel.gov.br/dados/>. Acesso em: 07 set. 2019

BECKER, B. K.; EGLER, C. A. Brasil: uma nova potência regional na economia mundo. 1. ed. Rio de Janeiro: Bertrand Brasil, 1994. 267p.

BESSA, K. A dinâmica da rede urbana no Triângulo Mineiro: convergências e divergências entre Uberaba e Uberlândia. 1. ed. Uberlândia: [s.n.], 2007. 348p.

BRANDÃO, C. A. Triângulo: capital comercial, geopolítica e agroindústria. 1989. 189 f. Tese (Doutorado em Desenvolvimento e Planejamento Regional) - Universidade Federal de Minas Gerais, Belo Horizonte. 1989.

Telecomunicações e dinâmica regional do Brasil. 1996. 244 f. Tese (Doutorado em Economia) - Departamento de Economia, Universidade Estadual de Campinas, Campinas, 1996.

BRASIL. Instituto Nacional de Geografia e Estatística. Conselho Nacional de Estatística. Anuário Estatístico do Brasil. Rio de Janeiro: Serviço Gráfico do Instituto de Geografia e Estatística, Ano XXIV, 1963. Disponível em: <https://biblioteca.ibge.gov.br/visualizacao/periodicos /20/aeb_ 1963.pdf>. Acesso em: 10 jul. 2018.

. Instituto Nacional de Geografia e Estatística. Conselho Nacional de Estatística. Anuário

Estatístico do Brasil. Rio de Janeiro, v. 32, p. 1-832, 1971. 
. Instituto Nacional de Geografia e Estatística. Conselho Nacional de Estatística. Anuário Estatístico do Brasil. Rio de Janeiro, v. 34, p. 1-964. 1973.

. Instituto Nacional de Geografia e Estatística. Conselho Nacional de Estatística. Anuário Estatístico do Brasil. Rio de Janeiro, v. 41, p. 1-840, 1980.

BRASIL. II Plano Nacional de Desenvolvimento (1975-1979). Rio de Janeiro: Serviço Gráfico do IBGE, 1974. 149p.

BRASIL. Decreto no 2.534 de 2 de abril de 1998. Aprova o Plano Geral de Outorgas de Serviço de Telecomunicações prestado no regime público. Disponível em < http://www.planalto.gov.br/ccivil_03/decreto/D2534.htm >. Acesso em: 29 mar. 2019.

BRASIL. Resolução $n^{\circ}$ 614, de 28 de maio de 2013. Aprova o Regulamento do Serviço de Comunicação Multimídia. Disponível em: <http://www.anatel.gov.br/legislacao/resolucoes/ 2013/465-resolucao-614 >. Acesso em: 30 mai. 2019.

CAPEL, H. Los ferro-carriles en la ciudad: redes técnicas y configuración del espacio urbano. 1. ed. Barcelona: Fundación de los Ferrocarriles Españoles, 2011. 223p.

CASTELlS, M. A sociedade em rede. Tradução de Roneide Venancio Majer. 8. ed. São Paulo: Paz e Terra, 2005. 630p.

CASTILHO, D. Modernização territorial e redes técnicas em Goiás. 1. ed. Goiânia: Editora UFG, 2016. 228p.

CAPRA, F. Vivendo redes. In: DUARTE, F.; QUANDT, C.; SOUZA, Q. (Orgs.). O tempo das redes. São Paulo: Perspectiva, 2008.

CORRÊA, R. L. Corporação e organização espacial: um estudo de caso. Revista Brasileira de Geografia. Rio de Janeiro, v. 53, n. 3, p. 33-66, 1991.

Trajetórias Geográficas. 7 ed. Rio de Janeiro: Bertrand Brasil, 2014. 302p.

CLEPS JR., J. Dinâmica e estratégias do setor agroindustrial no cerrado: o caso do Triângulo Mineiro. 1998. 291 f. Tese (Doutorado em Organização do Espaço) - Universidade Estadual Paulista Júlio de Mesquita Filho, Rio Claro, 1998.

DIAS, L. Os sentidos da rede: notas para discussão. In: DIAS, L. C.; SILVEIRA, R. L. L. (Org.). Redes, sociedade e territórios. Santa Cruz do Sul: EDUNISC, 2005.

. Redes eletrônicas e novas dinâmicas do território brasileiro. In: CASTRO, I. E.; GOMES, P. C.; CORRÊA, R. L. (Orgs.) Brasil: questões atuais da reorganização do território. Rio de Janeiro: Bertrand Brasil, 2008. p. 115-144.

DUPUY, G. El urbanismo de las redes: teorías y métodos. 1. ed. Barcelona: Oikos-Tau, 1997. $215 p$.

GUIMARÃES, E. N. Infra-estrutura pública e movimento de capitais: a inserção do Triângulo Mineiro na divisão inter-regional do trabalho. 1990. 224 f. Dissertação (Mestrado em 
Desenvolvimento Regional) - Departamento de Economia, Universidade Federal de Uberlândia, Uberlândia, 1990.

Formação e desenvolvimento econômico do Triângulo Mineiro: integração nacional e consolidação regional. 1. ed. Uberlândia: EDUFU, 2010. 254p.

HAGERSTRAND, T. Inovation diffusion as a spatial process. Chicago: The University of Chicago Press, 1967, 334 p. Disponível em: < https://archive.org/details/in.ernet.dli.2015.120140 >. Acesso em: 01 jun. 2017.

HARVEY, D. A produção capitalista do espaço. 4. ed. São Paulo: Annablume, 2005. 252p.

JORNAL DO BRASIL. Rio de Janeiro: 1891-2018. Diário. Disponível em: < http://bndigital.bn.gov.br/hemeroteca-digital/>. Acesso em: 25 jun. 2018.

JORNAL DO COMMERCIO. Rio de Janeiro: 1827-2016. Diário. Disponível em: < http://bndigital.bn.gov.br/hemeroteca-digital/>. Acesso em: 15 jun. 2018.

MARX, K. O capital: crítica da economia política. Livro I: o processo de produção do capital. 5. ed. São Paulo: Bointempo, 2013. 894p.

MAZZALI, L. O processo recente de reorganização agroindustrial: do complexo à organização "em rede". 1. ed. São Paulo: Editora UNESP, 2000. 175p.

MUSEU DA PESSOA. História de Rondon Pacheco. Disponível em: <http://www. museudapessoa.net/pt/conteudo/historia/historia-de-vida-46070>. Acesso em 20 jul. 2018.

NORTH, D. Instituições, mudança institucional e desempenho econômico. Tradução de Alexandre Morales. 1. ed. São Paulo: Três Estrelas, 2018. 255p.

SANTOS, M. Técnica, espaço e tempo: globalização e meio técnico-científico informacional. 5. ed. São Paulo: EDUSP, 2008. 174p.

$394 p$.

A natureza do espaço: técnica e tempo, razão e emoção. 4. ed. São Paulo: EDUSP, 2012.

SANTOS, M.; SILVEIRA, M. L. O Brasil: território e sociedade no início do século XXI. 15. ed. Rio de Janeiro: Record, 2011. 475p.

PIRES DO RIO, G. Organizações empresariais, trajetórias espaciais e racionalidade: espaço e tempo de uma empresa de celulose. Território, Rio de Janeiro, v. 5, n. 8, p. 101-119, 2000.

. A espacialidade da economia: superfícies, fluxos e redes. In: CASTRO, I. E.; GOMES, P. C. C.; CORREAA, R. L. (Org.). Olhares geográficos: modos de ver e viver o espaço. Rio de Janeiro: Bertrand Brasil, 2012. p. 155-187.

TEIXEIRA, T. Bandeirantes e pioneiros do Brasil Central. 1. ed. Uberlândia: Uberlândia Gráfica Ltda., 1970. 544p. 667p.

TELEBRÁS. Relatório de administração de 1983. Disponível em: <http://www.telebras.com.br /inst/wp-content/uploads/2011/03/RA1982.pdf> . Acesso em: 18. jun. 2018. 
Relatório Telebrás de 1990. Disponível em: <http://www.telebras.com.br/inst/wpcontent/uploads/2011/03/RA1973.pdf>. Acesso em 18. jul. 2018.

UEDA, V. Inovação tecnológica e espaço urbano: a implantação da Companhia Telefônica Melhoramento e Resistência em Pelotas/RS. 1998. 152 f. Dissertação (Mestrado em Geografia) Universidade Federal de Santa Catarina, Florianópolis, 1998.

Innovación tecnológica y cambio social: agentes y estratégias en las redes de telecomunicaciones en Rio Grande do Sul, Brasil. 2002460 f. Tese (Doutorado) - Departamento de Geografía Humana, Universidad de Barcelona, Barcelona, 2002.

SILVA. A. P. Com o suor do teu rosto: biografia do Comendador Alexandrino Garcia. 1. ed. Uberlândia: SABE, 1993. 152p.

SILVA, C. A. F. Grupo André Maggi: corporação e rede em áreas de fronteira. 1. ed. Cuiabá: Entrelinhas, 2003. 222p.

Trabalho enviado em 03/12/2019

Trabalho aceito em 11/12/19 